\title{
ORGANIZATION CULTURE IMPACT TO PERFORMENT HOTEL EMPLOYE (CASE STUDY :HOTEL LEGIAN RESORT -BALI)
}

\author{
I Wayan Pantiyasa, Michelle. \\ Sekolah Tinggi Pariwisata Bali Internasional \\ pantiyasawayan@yahoo.com, michelle0906a@gmail.com
}

\begin{abstract}
Organisational culture is a set of values or personality that is implemented by certain company or hotel as a form of identity of that hotel or company. The effect of organisational culture is profound, and correlates heavily towards employee performance by enhancing individual performance and increasing employee retention.

This research is conducted to discover the effect of organisational culture towards employee performance in Padma Resort Legian. The hotel's established core values points are used by measuring the effect of each core values towards employee performance. Whereas the core values that had been established is as follows; achievement, excellence, customer focus, honesty and integrity and people oriented. Quantitative and qualitative method is used as a tool to unravel the connection between organisational culture towards employee's performance. Later on questioners that had been distributed to 119 respondents by using likert scale measurement. The data then is analysed by using both simple and multiple correlation to measure the corelation between the core values towards employees performance both entirely or partially.

The result of the research shows that there is a correlation between organisational cultures towards employee's performance entirely, although only achievement and customer focus that show a significant value of correlation towards employee's performance.
\end{abstract}

Keywords: Organisational Culture, Employee Performance

\section{Introduction}

In the hospitality industry that had matured vastly, each hotel is competing among themselves to create a unique identity for the service that is given to their guest. By creating a service identity, each hotel hopes to be able to create a distinguishable differentiation for their service delivery. With the high number of competitiveness in the industry, cooperate identity has become a factor that determines the continuity of the company itself.

For the sake of creating a differentiation, each company creates their own corporate culture that goes along with their corporate identity. According to Henry Schein, Corporate culture had been utilized by researchers and managers to refer to the climate and practices of that organizations develop around their handling of people or to the espoused values and credo of an organization. 
On the other hand, employees is a tool and instrument that is significant in producing the products that are being offered by the company. By developing values that would become the employees guidelines, a condusive environment that supports the employees in performing is hoped to be achieved throughout the company. Supporting this theory, Kotter (1992: 16) adds that a strong corporate culture will enhance the business performance by enhancing a level of unusual motivation from the employees.

Whitman, Rooy, and Viswesvaran along with Williams and Anderson (cited by Keijzers, 2012) supports this statement by declaring that employee satisfaction increases not only the performance of employees but employee productivity and customer satisfaction as well. The same notion is supported by Denison $(1984,1990)$ who states that company with participatory culture acquire a bigger value on their return of assent and a double value of return on investment compared to company who does not.

Aside from the financial gain that the company is exposed to, organisational culture is closely related to employee performance. Employee performance itself is an output of process and an activity. This is being explained by Schein, cited by O'Donnell $(2008 ; 5)$ that stressed organisation culture being depicted as our character or character of an individual, that is guided and constrain by our behaviour, culture guides and constrain the behaviour of group members through norms, values, and customs that had been established within the organisation.

Padma Resort Legian is one of the accommodation provider in Bali that had been established for 25 years. As one of the five star accommodation provider, Padma Resort Legian had realised the importance of organisation culture by cultivating vision, mission and core values that define their service identity. The management had invented various means and ways to embed organisational culture throughout the individual that contributes and work in the hotel, from giving introduction regarding of Padma's philosophy during the new recruits orientation, to daily reminders of the core values points of Padma Resort Legian.

This research is conducted to measure the success of the management effort in communicating the company's core values, especially during interactions of employees and guest. Hopefully through this research, the management would gain insight regarding of the implementation of organisation culture by the employees. below:

According to the illustration above, the research questions are presented as

1. Is there any positive relationship exposed by achievement, excellence, customer focus, honesty and integrity and people oriented values simultaneously towards employee's performance?

2. Is there any positive relationship exposed by the value of achievement value towards employee performance partially?

3. Is there any positive relationship exposed by the value of excellence value towards employee performance partially?

4. Is there any positive relationship exposed by the value of customer focus towards employee performance partially?

5. Is there any positive relationship exposed by the value of honesty and integrity towards employee performance partially? 
6. Is there any positive relationship exposed by the value of people oriented towards employee performance partially?

\section{LITELATURE REVIEW}

\subsection{Organisational Culture}

Nadler M \& Nadler D(1998) described organisational culture that is identified as a principal value that is believed within a company, a phenomena that is experienced, believed and demonstrated. Explained further by Hallet (Cited by Ojo, 2009), Organisational culture can be expressed through thoughts, intents, actions, and interpretation of members of the organisation.

Organisational culture is important for the organisation continuity, as had been expressed by some researchers in their researches. Organisation culture is linked to various other factors such as the company's revenue, employee's satisfaction, guest satisfaction and periodical purchase. (Gillespie: 2007)

According to Schein (1985), organisational culture refers towards an integrated system of understanding that is held by each member of the organisation, that differentiates the organisation from the others.

Robbins (1994), categorises organisational culture characteristics as organisation dimension that can be defined and measured to gain insight on the basic character of the organisation, such as:

- Individual Initiative, shows the extent to which the organisation gives each member space and responsibility of their work.

- Risk Tolerance shows employees within an organisation are encourage to take risks.

- Direction indicates how the goals and objective of the company is being explained and attained.

- Integration, describes the degree of coordination of the company's departments.

- Management support is a character that shows the support that is given by the company towards its members.

- Control is a character that explains the degree of supervision that is carried out by the organisation towards it's member.

- Identity is a character that shows the extent employees identified themselves within an organisation, as opposed to identifying themselves in groups.

- Reward system, shows the reward and punishment system that is used by the company.

- Conflict Tolerance is a character that shows the extent to which conflict and constructive criticism is allowed within a company.

Schein $(2004 ; 26)$ in Organisational Culture and Leadership explains that a company's culture can be divided into three phase, namely:

- Artefacts. At this stage, culture can only be seen and felt. However, in this stage, an individual needs to divulge further to understand the meaning that lays from the organisation culture that is felt. If the individual stays within the company for longer period of time, the meaning of artefacts will become clearer. By analysing the values, norms and regulations that is done by the members daily, we will gain deeper understanding of this stage. 
- Espoused Beliefs and Values. In this stage members of organisation will determine the type and culture by consensus. In this phase, members of the organisation will create the value and norms that will be used within their group.

- Basic Underlying Assumptions. The same as theories that had been circulating, this phase is difficult to be confronted and change. Value and norms that had been formed in the previous phase will be embedded and become an uncompromising idea.

Denison (Cited by Ahmad, 2012), created organisation model that is based of four culture traits, as follows:

- Involvement. This characteristic states that an effective organisation by cooperation and giving authority to each organisation member.

- Consistency. This characteristic states an organisation is likely going to be effective if they have a strong and consistent organisation that which is coordinated and integrated well.

- Adaptability is an organisation hallmark that has high adaptability. Companies that have high adaptability are usually driven by their costumers and takes risks by making changes.

- Mission, is the nature of successful company who has clear vision and mission and is able to explain their position in the future.

Hodgetss and Luthans (2003: 170) suggests some of the characteristic of an organisational culture as follows;

- Norms that is measured based on certain things; such as jobs that are accomplished, and the level of cooperation from management and employees of an organisation.

- Rules that are defined by the employees behaviour that is closely related to productivity, corporation of each group and customer relationship.

- Behaviour that can be observed on a regular basis, such as the same language usage, and formal procedures.

In a research that is conducted by Ojo olu, it is shown that organisation culture impacts level of performance of employees and the productivity level of that organisation. The same result is shown by Fakhar Shahsad $(2012 ; 984)$ that stated organisational culture impacts the performance of employees and at the end will impact the productivity and performance of the organisation.

\subsection{Organisation Culture in the Hospitality Industry}

In Managing Human Resources in the Hospitality Industry, it is explained further regarding the effects of organizational culture on the company's operations. An organizational culture that has been built and created would be reflected on the "moments of truths", which can be defined as the time when an employee interacts with guest and requires quick decision making.

Nickson, Dennis (2007: 51) explains that a company that is engaged in the field of tourism and hospitality often seek candidates in accordance with the culture that the company owned. In much more detailed explanation, organizational culture can be expressed from a variety of things that is met in the hotel, ranging from the usage of furniture model, hotel logo, and the usage of certain languages by employees. 


\subsection{Values in the Organizational Culture in Padma Resort Legian}

The core values are such follows;

\subsubsection{Achievement}

The success of a company can be measured by administering target of achievement in each side of the job. Padma Resort Legian that is believed by Padma Resort Legian is supported by Pulakos (2004:4) who states that performance management can be done by exposing the bigger picture towards the employees, providing regular feedback and expectation and by developing through experience.

Scheiner (Cited by Truong, 2012), described in more detail by stating that by providing a target is a part of the first stage in the performance management chart.

\subsubsection{Excellence}

Dahgarrd, J (Cited by Qawasheh, 2013) mention a superior business can be defined and achieved through superior human, superior fellowship, excellent process, and by a superior product.

This is explained further by Sasmita \& Nayantara (cited by Qawasmeh, 2013 ) that states an organisation that demands perfection needs to provide a vision towards their employees, and also link the perfection of the activities and processes, evaluate perfection, empowering employees and the usage of technology and support learning process.

\subsubsection{Customer Focus}

The importance of corporate culture oriented company is mentioned by Mohammadpour Amir (2014) which states that the customer is one of the company's biggest asset and a company nowadays is customary to see from a customer's perspective and try to understand and satisfy them under a highly competitive environment.

Zemke and Shaaf (1989: 31) explains that there are five principals of the companies that use customer service approach;

1. The company will listen, understand and respond to the needs and expectations of their customers.

2. The company will define clearly the notion of the excellent services and communicating it all to employees.

3. They will create a quality standard of service and will be measured periodically by using those standards.

4. They will select employees with more caution and be train extensively to support the interaction that will take place with the customers.

5. They will give you an appreciation of the achievement of the service, both individually and as a group.

\subsubsection{Honesty and Integrity}

Desson (2010) said that the integrity of a company will show that the company appreciates the organisation's honesty, high ethical standard and an output that can be trusted. This is shown by Padma Resort Legian by including honesty and integrity in the core values of the company. 
Mentioned by Jarratt (2002: 24), that among the various dimensions of the organisational, actions that are based by integrity has the highest correlation towards the process of shaping relation between companies. Strong sense of honorship of honesty and justice are fundamental for effective communication and by building business relationships in the long term.

2.2. Employee Performance

\subsubsection{Performance}

Mangkunegara (2005) said that performance is derived from actual performance ( work performance or achievement that is obtained by an individual) can be interpreted as the result of quality and quantity of work achieved by an employee in performing their duties accordance with the responsibilities that are given.

Irianto (2001) adds that the employee's performance can also mean the result of many individual tasks or jobs created continuously by employees in a period.

Robbins stated that there are three criteria in assessing the individual performance are individual tasks, individual behaviour, and individual characteristics. Robbins explains further by adding that performance is a result of the ability (A), Motivation (M) and Opportunity (O).

\subsubsection{Factors that Affects Performance}

According to Mangkunegara (2007), performance is a multidimensional construction that includes many factors, such as;

a. Performance factors, including: knowledge, skills, abilities, self-confidence, motivation and commitment possessed by each individual.

b. Leadership factors, including: quality in giving impetus, encouragement, guidance, and support given by manager or team leader.

c. Teamwork factors, including: the quality of support and spirit that is given by co-workers by the organisation, organisation process, and performance culture within an organisation.

d. Contextual factors (situational), includes pressure and the change of internal and external environment.

Based on Simanjuntak (2005, 11-13), the performance of every single individual can be categorized into three groups, namely:

a. Individual competencies, which include skills and abilities to work.

b. Support organization, which includes the supply and quality of infrastructure, selection of technologies, the comfort of the working environment, as well as the terms and conditions of employment.

c. The performance of each person depends on the ability of their leader.

Based on the understanding of the experts it can be concluded that apart of a person's individual internal factors and external factors such as the type and capacity of their leader and the corporate's culture performance on each individual.

\subsubsection{Measurement of performance}


Performance within an organization is periodically measured. The variables of the measurements are; subject (input), behaviour (process) and result (output).

Mahmudi classified the performance measurement into three;

a. Performance based on subject. This assessment is focused on employee input. This revolves on the executant attributes, characteristic and personal quality that is viewed as the first factor.

b. Performance based on attitude, concentrates on process of the job carried out by an individual.

c. Performance based on result, focuses on the performance measurement input and output. Thus the performance management and appraisal techniques focused on the result measurement created.

According to Gorda (2005: 93), the aspects considered in the employee performance activities, are as follows;

a. Honesty

Employee honesty in executing their duties and responsibilities are by fulfilling promise, and their pledge to themselves, or their promise to God.

b. Loyalty

Loyalty of employee towards their duties and responsibilities is reflected by their willingness to maintain the company's image that is implemented by their loyalty towards employment agreement, loyalty towards products and quality, and their loyalty towards business relationship with others.

c. Creativity

Creativity shows the employee creativity ability of the employees to develop themselves and thinks creatively during work.

d. Performance

Employee performance focuses on the work of both of the quantity and quality according to the standards established in the job description.

e. Cooperation

Cooperation is a willingness to cooperate with employees that is associated with the task and responsibilities implementation and the willingness to motivate other employees to cooperate.

f. Discipline

Discipline focuses on the assessment of the ability to plan, organize, lead, and follow rules and policies that the company had issued and carry out the work accordance to the job description.

g. Leadership

Leadership focuses on the assessment of the ability to plan, organize, lead, control tasks and responsibilities in addition to being able to guide and move towards goal achievement that is genuine.

h. Intelligence

Intelligence focuses on the intelligence assessment of employees concerning of the aspects of spiritual intelligence, and the intelligence to change obstacles into opportunities.

2.3. The relationship of organisation culture towards employees performance 
There are various of results from previous studies that links organizational culture with employees performance. Denison and Mishra (1995) in Corporate Culture and organizational effectiveness found that organizational culture has low impact on sales volume and profit levels, but on the contrary it shows strong relationship with quality, employee satisfaction rate and overall organisation performance.

They also states that the high level of employee commitment can lead to increased performance of the individual, and in the end will increase the performance of the organisation.

This result is also supported by Kandula(2006) that describe that the key to excellent performance is a strong organisation culture. Kandula specifies in his research that the same strategy that is implemented by two different companies that works in the same industry and is located in the same area can produce different result because of the organisation culture.

Based on studies that have been held by Keijzer (2012) in the master's thesis titled the relationship between organizational culture and employee performance differences in mergers metioned that the good organizational culture influences the rising level of employee and commitment and satisfaction of employees, which will increase the level of employee performance.

Chatman and Bersade (1997) found that a strong organizational culture helps the performance of employees and the company as it creates something extraordinary inside the employees and provide structure and control needed by employees without having to rely on bureaucratic system that is formal and firm, which could lead to the decrease growth rate of motivation and innovation.

\subsection{Thinking Framework}

Furthermore, the thinking framework can be described as the chart below;

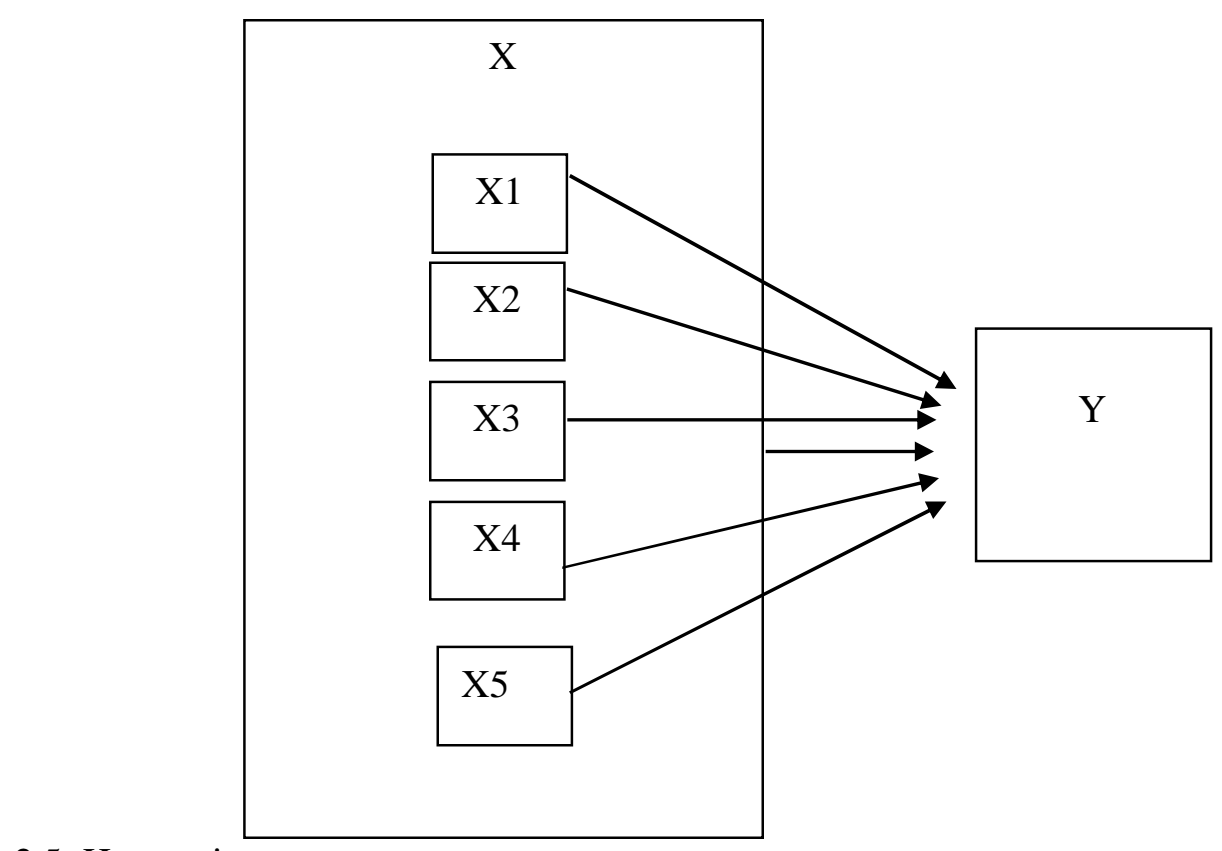

\subsection{Hypotesis}


Based on the research topic, the hypothesis or conclusion that can be drawn are;

$\mathrm{Ha}_{1}$ : There is a positive relationship of achievement, excellence, customer focus, honesty and integrity and people oriented on employee performance.

$\mathrm{Ha}_{2}$ : There is a positive relationship partially between achievement and employee performance.

Ha3: There is a positive relationship partially between excellence value on employee performance.

$\mathrm{Ha}_{4}$ : There is a positive relationship partially between customer focus value and employee performance.

Ha5: There is a positive relationship partially between honesty and integrity value and employee performance.

Ha6: There is a positive relationship partially between people oriented value and employee performance.

\section{RESEACH METHODS}

\subsection{Research Site}

Padma Resort Legian is a five star hotel that is located on J1 Padma No 1, Legian, Kuta.

$\begin{array}{ll}\text { Hotel } & : \text { Padma Resort Legian } \\ \text { Address } & : \text { Jl. Padma No. 1, Legian } 80361 \\ \text { Tel } & :+62,361,752,111 \\ \text { Fax } & :+62,361,752,140 \\ \text { website } & : \text { www.PadmaResortLegian.com }\end{array}$

\subsection{Type and Data Resources}

The data that is used in this research is classified as ordinal quantitative data, that can be separated as below:

a. Primary data; The questionnaire that had been distributed to the employees at Padma Resort Legian.

b. Secondary data; in the form of books and other researches.

\subsection{Operational Definition}

3.3.1. Organisational culture that is implemented in the hotel is taken from the hotel's core values, as follows:

- Achievement is the provision of goals and targets during the working time. This target can be in the form of sales target or the quality of guest comfort during their stay.

- Excellence is executing the tasks that are given on hand flawlessly and perfectly.

- Customer Focus is defining guest as their first quality. It is simply not enough only by meeting guest expectations, but if the chance arose, it is hope that the employees can exceed the guest's expectations if possible. It can be done by the simplest ways from being genuine towards the guests to ensuring the guest's needs are met. 
- Honesty and integrity is being honest and kind during interactions with guest or coworkers. This attitude can be implemented by being professional during work.

- People Oriented is believing and implementing the values of the company which is their most important asset.

3.3.2. Employee performance

Below are some aspects that influence employee performance;

- Work Quantity

This standard is done by comparing the volume of work that should be done by standard normal working with each employee's actual ability.

- Work Quantity

This standard is emphasised more on the quality of the work that is produced compared to the work volume.

- Time Utilization

Time utilization means that working time that is used according to the company's discretion.

3.4. Data Collection Technique

In this study, the data will be collected by passing out questionnaire that had been equipped by likert scale.

3.5. Data Analysis Techniques

3.5.1. Multiple Regression Analysis

Multiple Regression is used to figure the influence and relationship that is posed by two or more variables toward one dependent variable. This analysis is used to determine the direction of the relationship between independent variables and the dependent variable, whether each independent variable associate positively or negatively toward the dependent variable. This can be used to predict the value of the dependent variable if the independent variable increases or decreases as well. The formula is as below;

Where;

$$
\mathrm{Y}=\mathrm{a}+\mathrm{b}_{1} \mathrm{X}_{1}+\mathrm{b}_{2} \mathrm{X}_{2}+\ldots+\mathrm{bnXn}
$$

$$
\begin{array}{ll}
\mathrm{Y} & =\text { Dependent Variable } \\
\mathrm{X} 1 \text { and X2 } & =\text { Independent Variable } \\
\mathrm{a} & =\text { constant } \\
\mathrm{b} & =\text { regression coefficient (increase or decrease value) }
\end{array}
$$

\subsubsection{F Test}

This test is performed separately to determine the level of significance of the independent variabels influence together (simultaneously) on the dependent variable (Ghozali;2012). In this test, the F result value will be compared to $\mathrm{F}$ table on the significance degree of $96 \%$ or $\alpha=5 \%$ by considering the probability value that is smaller than $\alpha$ means that achievement, excellence, customer focus, honesty and integrity and people oriented have a positive together simultaneously toward the performance employee. This basis result can be taken by looking at the probability value (Ghozali; 2012) as follows; 
- When the significance probability value is $>0.005$, then HO is accepted and Ha is rejected, or simply said that there is no relationship of each variable towards the dependent variable.

- When the significance probability value is $<0.005$, then HO is rejected and Ha is accepted, or simply said that there is a relationship of each variable towards the dependent variable.

3.5.2. T-test

T-test is used to test the significance value of the relationship of the $\mathrm{X}$ and Y variabel and whether X1,X2,X3,X4 and X5 (achievement, excellence, customer focus, honesty and integrity and people oriented) really affect the $\mathrm{Y}$ variable (employee performance) separately or partially (Ghozali;2012)

\section{RESULTS AND DISCUSSION}

\subsection{Data analysis}

The data analysis technique that is used to expose the research result that had been explained briefly previously by using statistical analysis with SPSS as below;

Table 4. 1 Variable Analysis of Organisational Culture on Employee's Performance

\begin{tabular}{|l|c|c|r|r|}
\hline \multicolumn{1}{|c|}{ variable name } & B & beta & t & Sig. T \\
\hline Company culture & 0.261 & 0.493 & 6.13 & 0.001 \\
\hline $\mathrm{R}=0.493$ \\
$\mathrm{R}$ Square $=0.243$
\end{tabular}

\subsubsection{Correlation of Organizational Culture on Employee Performance}

Based on the table above 4.6. above, it can be seen that the independent variables are correlated simultaneously with employee performance with the significance value of $0.001<0.005$. Based on the significance value that had been resulted, it can be concluded that the organisational culture pose a significant and positive relationship on employee performance.

The value of $\mathrm{R}=0.493$ and $\mathrm{D}=0.243$ shows the determination coefficient. It shows that organisational culture shows $24.3 \%$ contribution on employee performance, and as much as $75.7 \%$ is influenced by other factors.

\subsubsection{Partial Correlation Analysis}

Stepwise method is used on the SPSS application to figure the variable that provide the biggest impact on employee performance. Stepwise method produces two models, which can be seen as below; 
Tabel 4.2. Stepwise Analysis

\begin{tabular}{|c|c|c|c|}
\hline Model & $\begin{array}{c}\text { Variables } \\
\text { Entered }\end{array}$ & $\begin{array}{l}\text { Variables } \\
\text { Removed }\end{array}$ & Method \\
\hline 1 & $\begin{array}{l}\text { achieveme } \\
\text { nt }\end{array}$ & & $\begin{array}{l}\text { Stepwise (Criteria: Probability-of-F-to- } \\
\text { enter }<=.050 \text {, Probability-of-F-to-remove } \\
>=.100) \text {. }\end{array}$ \\
\hline 2 & $\begin{array}{l}\text { customer } \\
\text { focus }\end{array}$ & & $\begin{array}{l}\text { Stepwise (Criteria: Probability-of-F-to- } \\
\text { enter }<=.050 \text {, Probability-of-F-to-remove } \\
>=.100) \text {. }\end{array}$ \\
\hline
\end{tabular}

a. Dependent Variable: kinerja karyawan

From the table above can be concluded that among all existing independent variables, achievement and customer focus are the variables contributes the most to the employee performance in Padma Resort Legian.

Table 4. 3 results for multiple correlation analysis coefficients $^{\text {a }}$

\begin{tabular}{|c|c|c|c|c|c|c|}
\hline \multirow{2}{*}{\multicolumn{2}{|c|}{ Model }} & \multicolumn{2}{|c|}{$\begin{array}{l}\text { unstandardized } \\
\text { Coefficients }\end{array}$} & \multirow{2}{*}{$\begin{array}{c}\text { standardized } \\
\text { Coefficients } \\
\text { beta }\end{array}$} & \multirow[b]{2}{*}{$\mathrm{t}$} & \multirow[b]{2}{*}{ Sig. } \\
\hline & & $\mathrm{B}$ & Std. Error & & & \\
\hline \multirow[t]{2}{*}{1} & (Constant) & 13493 & 2324 & & 5806 & .000 \\
\hline & achievement & 1,072 & .181 & .480 & 5917 & .000 \\
\hline \multirow[t]{3}{*}{2} & (Constant) & 9372 & 2,561 & & 3660 & .000 \\
\hline & achievement & .833 & .189 & .373 & 4,411 & .000 \\
\hline & customer focus & .496 & .151 & .278 & 3,287 & .001 \\
\hline
\end{tabular}

a. Dependent Variable: employee performance

From the table above, it can be seen that the independent variables are correlated variables simultaneously are achievement and customer focus with the significant level $0.000<0.005$

\subsubsection{Multiple Linear Regression Analysis}

In order to determine more clearly and in detail about the results of SPSS analysis that has been done, it can be seen from the table below: 
Table 4. 4. The results of multiple correlation analysis

\begin{tabular}{|c|l|c|c|c|c|}
\hline $\begin{array}{c}\text { Dependent } \\
\text { variable }\end{array}$ & \multicolumn{1}{|c|}{ variable name } & $\mathrm{B}$ & beta & $\mathrm{t}$ & Sig. T \\
\hline \multirow{4}{*}{$\begin{array}{c}\text { Employee } \\
\text { performance }\end{array}$} & Achievement & 0.833 & 0.373 & 4.411 & 0.000 \\
\cline { 2 - 6 } & Excellence & - & 0.101 & 0.989 & 0.325 \\
\cline { 2 - 6 } & Customer Focus & 0.496 & 0.278 & 3.287 & 0.001 \\
\cline { 2 - 6 } & Honesty and Integrity & - & 0.123 & 1.434 & 0.154 \\
\cline { 2 - 6 } & People Oriented & - & 0.181 & 2.155 & 0.33 \\
\hline $\begin{array}{l}\text { Achievement regression coefficient: } 0.833 \\
\text { Coefficient regression Customer Focus: } 0.496 \\
\text { Constants: 9372 }\end{array}$ & \multicolumn{4}{|l}{} \\
\hline
\end{tabular}

Both achievement and excellence influence on employee performance in Padma Resort Legian can be explained using multiple linear regression analysis with a model beneath;

$$
\mathrm{Y}=\mathrm{a}+\mathrm{b} 1 \mathrm{x} 1+\mathrm{b} 2 \times 2
$$

From the results of analysis using SPSS analysis, a multiple linear regression equation can be obtained as follows:

$$
\mathrm{Y}=9372+0.833+0.496 \mathrm{X} 3 \mathrm{X} 1
$$

From these equations can be described as follows:

1. Coefficient Regression achievement (b1) $=0.833$ is positive. The statistics can be interpreted as positive relationship occur between achievement and performance of employees at Padma Resort Legian. An increase of one unit of achievement will lead to improved value of employee performance as much as 0833, assuming customer focus (b2) it is fixed or constant.

2. Regression Coefficients Customer focus (b2) for 0.496 is positive. The statistics can be interpreted as positive relationship occur between customer focus and performance of employees at Padma Resort Legian. An increase of one unit of achievement will lead to improved value of customer focus as much as 0.496, assuming achievement (b1) fixed or constant.

\subsubsection{Hypothesis}

1. Simultaneous Significance Test (Test Statistic F)

Based on the value of $F$ that have been attached in Table 44. with significance $0.000<0.005$ means $\mathrm{Ho}$ is rejected. To serve as an additional explanation that has been described previously in Table 4.4, regarding the contribution value of achievement and customer focus, it can be concluded that the independent variables namely achievement and customer focus have significant influence on the dependent variable of employee performance.

\section{2. $\quad$ T test}

In order to see the effect of achievement and customer focus towards employee performance, t-test is conducted partially with the SPSS program. The result can be seen in table 4.4 . 
1. Hypothesis Test on the influence of achievement towards employee performance

Table 4.4 shows that the value of $\mathrm{t}$ obtained from the regression with SPSS amounted to 4,411 with significant value 0.000 . Due to the significant value of $\mathrm{t}<\alpha(0.005)$ then $\mathrm{H} 0$ is rejected. This means achievement pose an influence on employee performance.

2. Hypothesis Test on the influence of excellence towards employee performance

Table 4.4 shows that the value of $\mathrm{t}$ obtained from the regression with SPSS amounted to 0.989 with significant value 0.325 . Due to the significant value of $\mathrm{t}>\alpha(0.005)$ then $\mathrm{H} 0$ is accepted. This means excellence does not pose any influence on employee performance.

3. Hypothesis Test on the influence of customer focus towards employee performance

Table 4.4 shows that the value of $t$ obtained from the regression with SPSS amounted to 3.287 with significant value 0.001 . Due to the significant value of $\mathrm{t}<\alpha(0.005)$ then $\mathrm{H} 0$ is rejected. This means customer focus pose an influence on employee performance.

4. Hypothesis Test on the influence of honesty and integrity towards employee performance

Table 4.4 shows that the value of t obtained from the regression with SPSS amounted to 1.424 with significant value 0.154 . Due to the significant value of $\mathrm{t}>\alpha(0.005)$ then $\mathrm{H} 0$ is accepted. This means honesty and integrity does not pose any influence on employee performance.

4. Hypothesis Test on the influence people oriented towards employee performance

Table 4.4 shows that the value of t obtained from the regression with SPSS amounted to 2.155 with significant value 0.33 . Due to the significant value of $\mathrm{t}>\alpha(0.005)$ then $\mathrm{H} 0$ is accepted. This means people oriented does not pose any influence on employee performance.

\section{CONCLUSIONS AND SUGGESTIONS}

\subsection{Conclusions}

Based on the research that has been presented, the conclusion can be drawn as follows:

1. There is a positive and significant influence of corporate culture on employee performance in Padma Resort Legian.

2. Achievement variable pose a significant positive effect partially on employee performance variable in Padma Resort Legian.

3. Excellence variable doesn't pose a significant positive effect partially on employee performance variable in Padma Resort Legian.

4. Customer focus variable pose a significant positive effect partially on employee performance variable in Padma Resort Legian.

5. Honesty and Integrity variable doesn't pose a significant positive effect partially on employee performance variable in Padma Resort Legian.

6. People Oriented variable doesn't pose a significant positive effect partially on employee performance variable in Padma Resort Legian. 


\subsection{Suggestion}

Some suggestions can be submitted as follows:

1. Based obtained results, the management of Padma Resort Legian can use factors beyond organizational culture to enhance employee performance, such as the leadership style of the manager or supervisor and employee motivation.

2. Although the value of excellence, honesty and integrity and people oriented don't pose any effect on employee performance, but these values are very influential on employee satisfaction or the satisfaction of the guests who interact with employees. These values should continue to be cultivated in the company.

3. The Management of Padma Resort Legian is suggested to create and abide reward and punishment system that is to employees Padma Resort Legian.

4. In order to deepen the values of the organisation culture of Padma Resort Legian towards their employees, the management of Padma Resort Legian can use the story telling technique to employees Padma Resort Legian.

\section{REFERENCES}

Ahmad, Shakil, M. Impact of Organizational Culture on Performance Management Practices in Pakistan. Business Inteleggence JOURNALJanuary 2012 Vol 5 No 1 .

Denison, DR 1984 . Bringing Corporate Culture to the Bottom L ine. Organizational Dynamics, New York: Wiley.

Denison, Daniel R and Mishra, Aneil, 1995.Corporate Culture and Organizational Effectiveness. New York: Wiley .

Desson and Clouthier. Symposium on International Safeguards International Atomic Energy Agency. Vienna 3 November 2010 .

Gillespie, Michael. 2007. Linking organizational culture and customer satisfaction: Results from two companies in different industries. Physchology Press .

Gorda, I G. N, 2006. The Human Resource Management. Moulds third. Denpasar: Bali Astabrata.

Ghozali, I. 2005. Applications Multivariate Analysis with SPSS Program. Semarang: BP Diponegoro University, Semarang .

Hackman, et al. 1975. Behavior in Organizations. Mc -Graw Hills; New York .

Irianto, J., 2001. The themes Principal Resource Management. Insan Scholar; Surabaya 
Jarratt, Denise and Grant O'Neill. 2002. The Effect of Organization Culture on Business to Business Relationship Management Practices and Performances . Australasian Marketing Journal 10 (3)

Kandula, SR 2006. Performance Management, New Delhi: Prentice Hall of India private limited.

Keijzers. B , 2012, The Relationship between Organizational Culture and Employee Performance Differences in Mergers (Master Thesis). Tilburg University .

Kennedy, Allan A and Deal, Terrence E. 1982. Corporate Culture The Rites and Rituals of Corporate Life, Addison-Wesley Publishing Company : Boston .

Kotter, JP \& Heskett, JL 1992 . Corporate Culture and Performance. New York: Free Pass .

Luthans, Fred and Richard Hodgetts. 2003. International management; culture, strategy and behavior. United States: McGraw-hill .

Mathis, Jackson. 2006. Human Resources Management, edition of ten, Publisher Salemba Four .

Mangkunagara . 2005. Behavioral and Organizational Culture. Bandung: Rafika Aditama .

Mu rphy, KR, \& Cleveland, JN 1995 . Understanding Performance Appraisal: Social organizational and goal based on perspectives. Thousand Oaks: Sage Publications .

Nadler, M., and D. Nadler 1998 . Champions of change. Jossey-Bass publishers : San Francisco.

Nickson, Dennis. 2007. Human Resources Management for the Hospitality and Tourism Industries. Elsevier: Oxford.

Ojo, Olu. 2009 . Impact Assessment of Corporate Culture on Employee Job Performance. Business Intelliegence Journal - August 20092 vol .

Pulakos, Elaine, et al. 2004. Building a High Performance Culture; A Fresh Look at the Performance Management. SHRM Foundation; Virginia .

Robbins. Stephens P. 2001 . Principles of Organizational Behavior. Jakarta: Erland.

Shahzad, Fakhar.2012. Impact of Culture on Organizational Organizationall performanc: An Overview. Interdisciplinary Journal of Con tempora ry Research in Bu siness vol 3 No. 9 
Schein, Edgar H. 2005. Organizational Culture and Leadership third edition. San Francisco: John Wiley \& Sons, Inc.

Sharp, Isadore. 2009. The Four Seasons The Story of a Business Philosopher . Portfolio: New York .

Simanjuntak, J Payaman. 2003. Management and Performance Evaluation. Jakarta: Faculty of Economics Research Institute UI. '

Sirota, David. 2005. The Enthusiastic Employee: How Companies Profit by Giving Workers What They Want. Wharton School Pub: Pennsylvania .

Sugiyono. 2014. Quantitative Research Methods, Qualitative and $R \quad \&$ $D$. Bandung: Alfabeta .

Qawasmeh, Dr Farid Mohammad et al. The Role of Organization Culture in Achieving Organizational Culture: Jadara as a Unique Study. International Journal of Economics and Management Sciences. Vol 2 No 7 .

Truong, Ngo Cong. 2012. The Impact of Organizational Factors on Employee Performances in viatnamese Companies. Thesis Master of Business at the Faculty of Economics Hoi Chi Minh City, Vietnam.

Toole, James and Bennis, Warren. A Culture of Candor. Harvard Business Review, June 2009 issue (cited April 2). Available from: https://hbr.org/2009/06/a-culture-of-candor

Main, Rai \& Mahadewi 2012, Tourism and Hospitality Research methodology, Yogyakarta : CV.Andi offest.

The main, I Gusti Bagus Raid and Mahadewi, Ni Made Eka. Tourism and Hospitality Research Methodology. 2012. AND; Yogyakarta

Wheelhouse, David CHRE. 1989 Managing Human Resources in the Hospitality Industry. AHLEI: Michigan .

Zemke, Ron and Schaaf. 1989. The Service Edge: 101 Companies that Profit from Customer Care. New York; New American Library: New York. 